International scientific and technical conference

DOI: $10.34185 / 1991-7848 . i t m m .2020 .01 .034$

\title{
АВТОМАТИЗОВАНИЙ КОМПЛЕКС МОНТТОРИНГУ ЕНЕРГОНОСІЇВ НА ДНІПРОВСЬКОМУ КОКСОХІМІЧНОМУ ЗАВОДІ
}

Заславський О.М. к.т.н., доцент, Карпенко О.В, Проценко С.Н., Ткачов В.В. д.т.н., професор

Дніпровська політехніка, Україна

Ключові слова: МОНТТОРИНГ, ЕНЕРГОРЕСУРСИ, МЕРЕЖА, МІКРОПРОЦЕСОР.

Перехід до принципово нової парадигми соціально-економічного розвитку країни: від орієнтації переважно на споживання природних ресурсів, до високотехнологічних виробництв забезпечується використанням IT- технологій, сучасних засобів комунікації та цифрових процесів. Перед розробниками такої системи стоять задачі забезпечити в процесі моніторингу [1] виконання наступних вимог: повноти охоплення джерел первинної інформації, 3 врахуванням цифрової революції та революції енергетичної [2,3], подальшого вдосконалення, розробки нових, більш точних і досконалих зразків [4], вирішення задачі обчислення енергетичних балансів у будь-якій деталізації; своєчасного виявлення, локалізації та усунення втрат від несанкціонованого відбору; зниження власного споживання енергоресурсів на господарські потреби; можливості розширення обсягу й функціональності системи без значних матеріальних витрат [5].

Запропонована узагальнена структурна схема комплексу, (рис. 1.) яка реалізує функції моніторингу енергетичних потоків, здійснює автоматичний збір інформації щодо питомих та поточних витрат електричної енергії, різних газів, пару, стиснутого повітря, води та інших рідин, що використовуються або виробляються у технологічних процесах. 


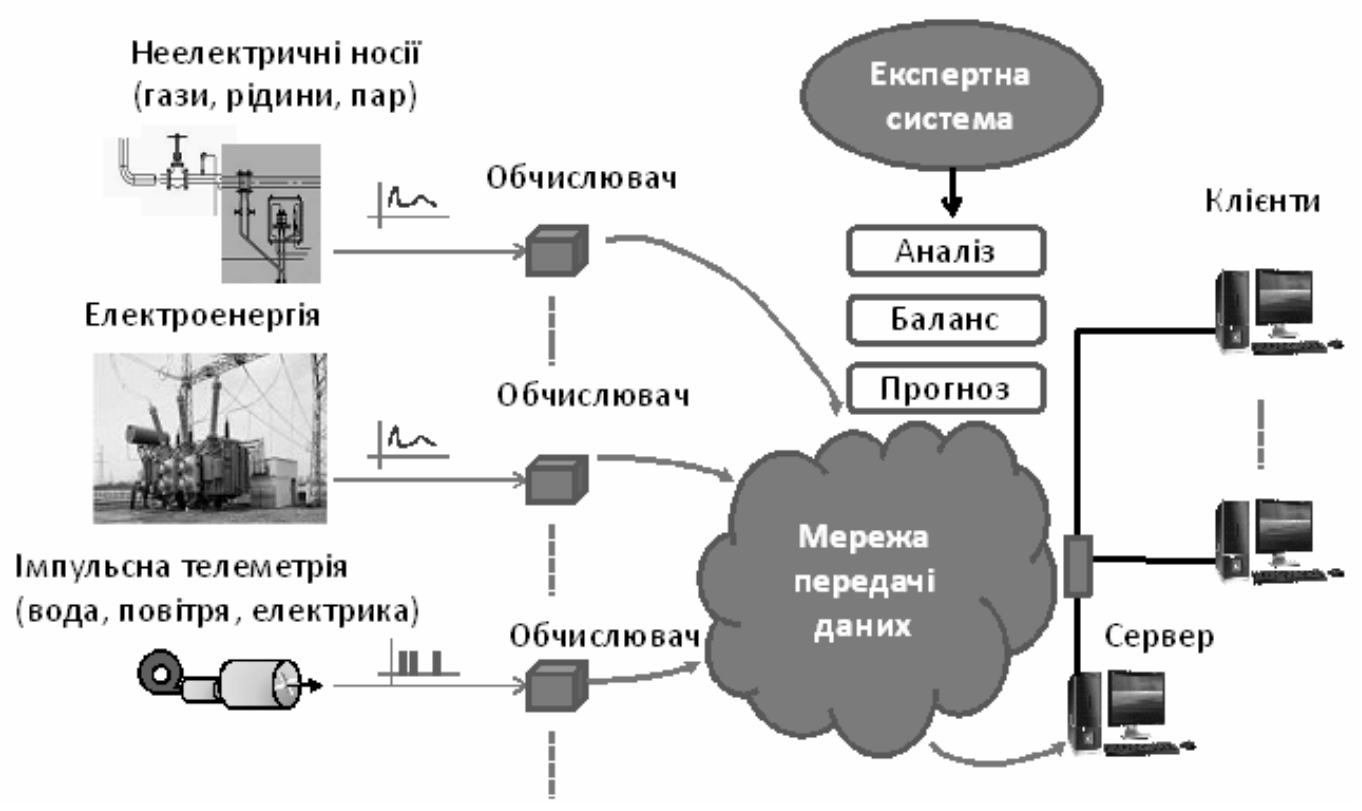

Рисунок 1 - Узагальнена структурна схема комплексу моніторингу енергетичних потоків

Для цього в составі комплексу передбачено наступні функціональні складові (рис 2).

a)
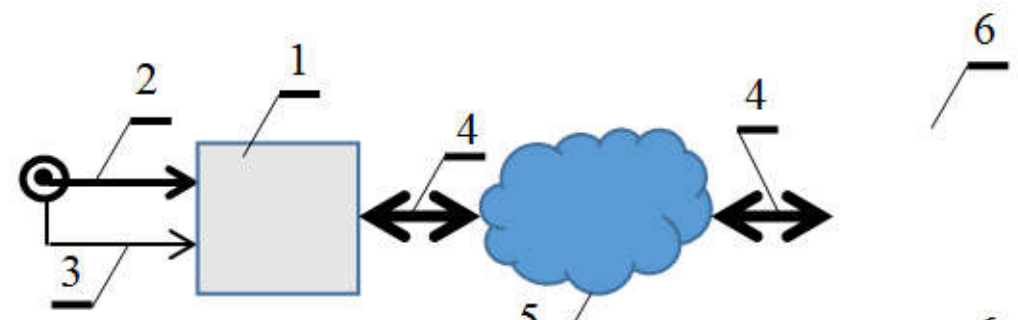

б)
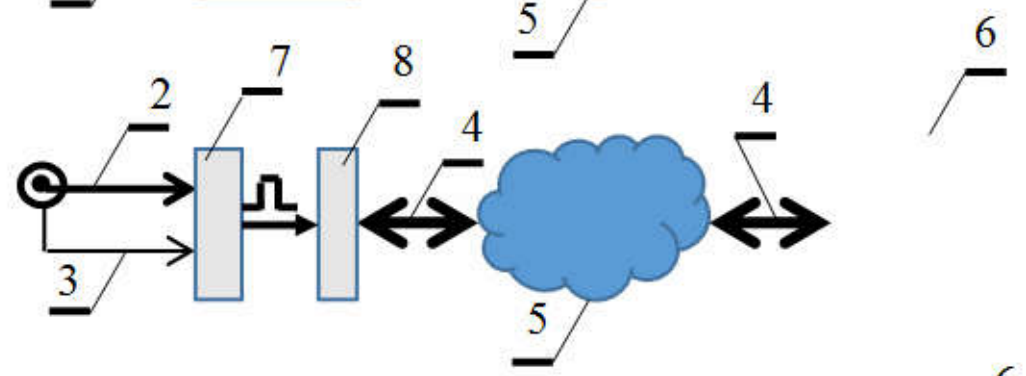

B)

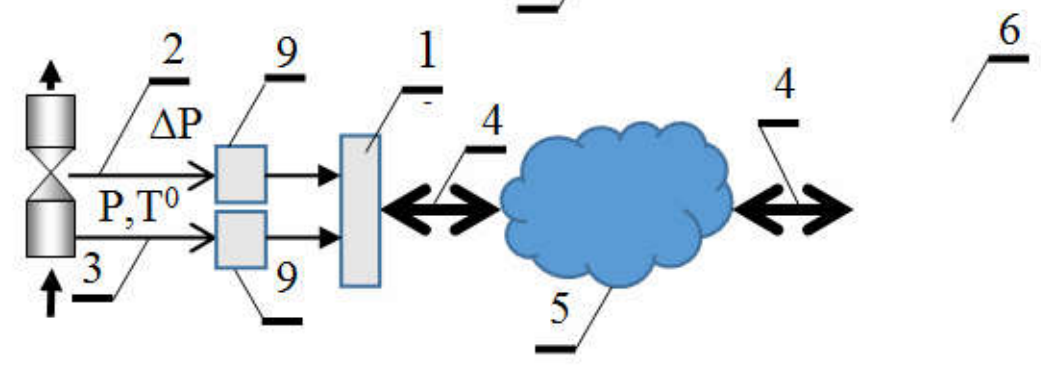

Рисунок 2 - Перетворення поточних параметрів та інтегрованих величин витрат енергоносіїв у послідовний код в системах моніторингу енергетичних потоків 
International scientific and technical conference Information Technologies in Metallurgy and Machine building - ITMM 2020

Де 1 - інтелектуальний лічильник, 2 - сигнали відображення інтенсивності енергетичного або матеріального потоку, 3 - сигнали відображення параметрів потоку, 4 - послідовний інтерфейс, 5 - мережа передачі даних, 6 - сервер моніторингу енергетичних потоків, 7 - перетворювач електричної потужності або інтенсивності матеріального потоку у частоту імпульсів, 8 інтелектуальний тарифікатор, 9 - перетворювач.

Неодночасність $|\tau|>0$ вимірів струму та напруги призводить до похибки обліку електричної енергії [6]. Автоматична компенсація цієї похибки, а також похибок, що зумовлені не лінійністю вимірювального тракту забезпечуються саме інтелектуальними можливостями лічильника [7]. В разі якщо зчитування даних з пам'яті інтелектуальних лічильників електричної енергії здійснюється по силовій мережі, в якій вони виконують вимірювання (PLC-технологія), внаслідок впливу високочастотних сигналів може виникати додаткова похибка обліку, що пов'язана 3 «підміною частоти - аліасінгом» [8]. Для запобігання цьому негативному явищу в системі моніторингу 3 використанням PLCтехнології необхідно узгоджувати частоту сигналів зчитування даних 3 кількістю N відліків сигналу напруги.

\section{Література}

1. Шваб К. Четвертая промышленная революция [Електронний ресурс] / К. Шваб. - М. : Эксмо, 2016. - 138 с. - Режим доступу : http://www.eurasiancommission.org/ru/act/dmi/ workgroup/materials/Pages_2016.pdf.

2. Доклад о мировом развитии 2016: Цифровые дивиденды. Обзор [Електронний ресурс] / Международный банк реконструкции и развития / Всемирный банк. - Режим доступу

https://openknowledge.worldbank.org/bitstream/handle/10986/23347/210671RuSum.pdf?se quence $=16$.

3. Білецький В. С. Основи нафтогазової справи / В. С. Білецький, В. М. Орловський, В. І. Дмитренко, А. М. Похилко. Запоріжжя : Успіх-Принт, Київ: ФОП Халіков Р. Х., 2017. $312 \mathrm{c}$.

4. Лір В., Тімченко О. Цифровий моніторинг як механізм формування енергетичного балансу національного господарства. Схід №1 (153) січень - лютий 2018p.

5. Мониторинг использования энергересурсов как инструмент энергосбережения [Електронний ресурс]. - Режим доступу : http://forum.efind.ru/showthread.php?t=89692. 
6. О.М. Заславський, В.В. Кухарчук. Вимірювання електричної енергії методом безпосереднього інтегрування та подвійного сканування миттєвих значень струму та напруги. Оптико-електронні інформаційно-енергетичні технології. - 2008. - №1 (15). - C.191 - 196.

7. В.В. Кухарчук, О.М.Заславський. Комп’ютеризована система обліку електричної енергії. Вінниця , ВНТУ, 2012. - 152 с. (монографія ).

8. Теоретичні основи комп’ютерних систем збирання, перетворення та передачі інформації: підруч. /О.М. Заславський, К.В. Соснін, Д.С. Зибалов, Д.В. Славінський, Є.К. Воскобойник; М-во освіти та науки України, Нац. техн. ун-т «Дніпровська політехніка». - Дніпро: НТУ «ДП», 2019. - 292 с.

\section{AUTOMATED ENERGY CARRIERS MONITORING COMPLEX AT THE DNIPROVSK COKE CHEMICAL PLANT}

\section{Zaslavsky Alexander, Protsenko Stanislav, Tkachov Viktor}

Abstract. Digital integrated monitoring of all types of energy sources with the use of expert systems for the analysis of their mutual correlations and forecasting provides in the large industrial enterprise efficient use of energy resources, identification of the main sources of losses, reduction of overconsumption, optimization of the distribution of purchased and manufactured energy sources. However, the introduction of such systems is constrained by the relatively high cost of specialized cost calculators, technical means for creating branched data networks and the lack of efficient algorithms for expert analysis of material and energy flows. The paper presents data on the innovative project of the energy monitoring system, features of its software and technical implementation. The principles and an example of construction of a system of monitoring of energy flows are considered. The system is intended for control of parameters and technical accounting of expenses of various energy carriers, including, gases, compressed air, liquids, steam, electricity.

Keywords: MONITORING, ENERGY CARRIERS, NETWORK, MICROPROCESSOR. 


\section{References}

1. Klaus Schwab The Fourth Industrial Revolution [Electronic resource] / Klaus Schwab. - M. : Эksmo, 2016. - 138 pp. - Access mode : http://www.eurasiancommission.org/ru/act/dmi/ workgroup/materials/Pages_2016.pdf.

2. Doklad o mirovom razvitii 2016: Tsifrovye dividendy. Review [World Development Report 2016: Digital Dividends] [Electronic resource] / International Bank for Reconstruction and Development / World Bank. - Access mode

https://openknowledge.worldbank.org/bitstream/handle/10986/23347/210671RuSum.pdf?se quence $=16$.

3. Bilets'kiy V. S. Osnovi naftogazovoï spravi [Basics of oil and gas business]/ V. S. Bilets'kiy, V. M. Orlovs'kiy, V. I. Dmitrenko, A. M. Pokhilko. Zaporizhzhya : Uspikh-Print, Kiïv: FOP Khalikov R. Kh., 2017. - 312 p.

4. Lir V., Timchenko O. Tsifroviy monitoring yak mekhanizm formuvannya energetichnogo balansu natsional'nogo gospodarstva [Digital monitoring as a mechanism for formulating the energy balance of the national statehood]. Skhid №1 (153) Jan - Feb 2018.

5. Monitoring ispol'zovaniya energoresursov kak instrument energosberezheniya [Monitoring the use of energy as a tool for energy conservation] [Electronic resource]. Access mode: http://forum.efind.ru/showthread.php?t=89692.

6. O.M. Zaslavs'kiy, V.V. Kukharchuk. Vimiryuvannya elektrichnoï energiï metodom bezposeredn'ogo integruvannya ta podviynogo skanuvannya mittevikh znachen' strumu ta naprugi. Optiko-elektronni informatsiyno-energetichni tekhnologiï. - 2008. - №1 (15). 191 - 196pp.

7. V.V. Kukharchuk, O.M.Zaslavs'kiy. Komp’yuterizovana sistema obliku elektrichnoï energiï. Vinnitsya, VNTU, 2012. - 152 p. (monograph).

8. Teoretichni osnovi komp'yuternikh sistem zbirannya, peretvorennya ta peredachi informatsiï: pidruch. /O.M. Zaslavs'kiy, K.V. Sosnin, D.S. Zibalov, D.V. Slavins'kiy, Є.K. Voskoboynik; Ministry of Education of Ukraine, National Technical University Dnipro Polytechnic. - Dnipro: University of Technology, 2019. - 292 p. 